\title{
Três contos, três textos: um argumento psicanalítico*
}

Philippe Willemart

Hoje, a teoria literária dificilmente aceita reduzir a obra literária a uma causa social ou a um inconsciente pessoal ou coletivo, como foi feito durante boa parte do século XX.

No entanto, desde a redescoberta do manuscrito literário em meados da década de 70, as perguntas sobre as origens da obra e o fazer poético voltaram à tona, questionando as posições estruturalistas de orientação marxista ou freudiana dos anos 60 .

Com efeito, como articular o conceito relativo ao sujeito do inconsciente do ser falante e a pluralidade textual de um autor? Muito próximo do escritor, o manuscrito mostra claramente a mão que escreve, hesita, rasura, escolhe, rabisca, recomeça. Como desligar do texto a mão movida pela pulsão do escritor? Como não restituir todos os textos pertencentes a um mesmo escritor a uma fonte única, o inconsciente do escritor? Como entender, portanto, a pluralidade literária e a mesmidade daquele que escreve?

Freud sempre considerou os clássicos como seus mestres, mas, extremamente ocupado pela elaboração e descoberta do inconsciente, não soube e não teve tempo de ordenar sua admiração pelos artistas, a não ser para confirmar a psicanálise - ver a Gradiva -, ou para tentar estabelecer uma ligação entre a técnica da obra de arte e a produção de prazer, - em uma análise do Moisés de Miguel-Ângelo -, ou mesmo, entre este mesmo prazer do espectador e as pulsōes do artista - na Lembrança de infância de Leonardo da Vinci -, conforme nos mostra a brilhante síntese de Paul Ricoeur ${ }^{1}$ feita para o colóquio de Cérisy em 1960.

Por outro lado, segundo indica Freud, os artistas e os escritores apontam vias desconhecidas mesmo aos psicanalistas; poderíamos exemplificá-las com a admirável descrição relativa ao gozo auditivo de Swann quando escuta a sonata de Vinteuil ${ }^{2}$, ou, ainda, com o gozo extraordinário da mulher adúltera de Camus no deserto, aspirando nômades e dromedários, vento e imobilidade, estrelas e constelaçôes ${ }^{3}$.

Paralelamente a esta boa crítica, existe a má crítica psicanalítica que reduz a literatura a um Édipo mal resolvido, a uma perversão definida ou a um incidente de infância, crítica que acabou contribuindo para perturbar as relações entre a psicanálise e a crítica literária.

* Esse texto foi redigido para o Séminaire Flaubert do Institut des textes et Manuscrits Modernes do CNRS (França), respondendo à pergunta polêmica de Jean Bellemin Noel: "Três contos: três textos ou um texto?". Os três contos de Gustave Flaubert Saint-Julien lHospitalier, Un coeur simple e Hérodias foram escritos entre o dia 15/9/1875 e $15 / 2 / 1877$.

${ }^{1}$ Entretiens sur L'art et la psychanalyse. Paris, Mouton, 1962. p. 29.

2 PROUST, M. La recherche du temps perdu. Paris, Gallimard, 1954. v. I, p. 236 e 237.

3 CAMUS, A. La femme adultère. L'Exil et le royaume. Paris, Gallimard, 1957. 


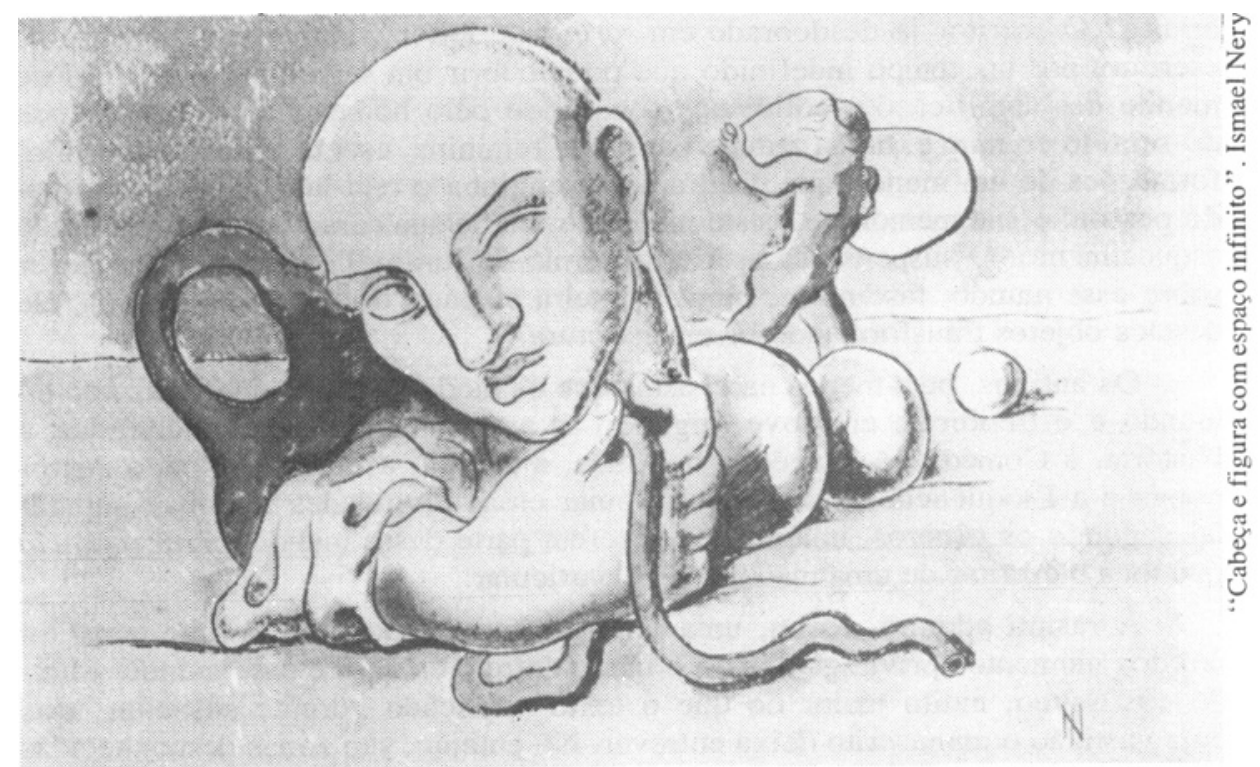

Como, portanto, ultrapassar essa aparente oposição entre o múltiplo textual e o um em sua dimensão inconsciente? Como funciona esta dialética na escritura? $\mathrm{Ou}$ ainda, como funcionam os mecanismos ou a fábrica da escritura?

Quando Jean Bellemin-Noel ${ }^{4}$ criou a noção de inconsciente do texto, ou seja, o trabalho de um fantasma de desejo, nos nos interrogamos sobre a origem desse desejo e concluímos provir do narrador, o que já era uma maneira de diversificar os textos, pois cada um deles vinha de um desejo singular.

Em seguida, estudando mais pormenorizadamente o manuscrito de Hérodias, do qual tomaremos os exemplos daqui em diante, pudemos verificar algo que só a posteriori parece uma evidência, o texto pode ser matematicamente definido como um conjunto de momentos conclusivos, ou melhor, como uma combinatória desses momentos. Cada tentativa, rasura, acréscimo ou deslocamento desemboca em um texto, o da edição, e, para Flaubert, pelo menos, tais textos conclusivos năo sāo necessariamente ligados ao conjunto do conto, mas, às vezes, a um capítulo, um parágrafo ou a uma frase.

$O$ texto $\epsilon$, portanto, transpassado por um desejo, o do narrador, desejo singular que vamos tentar descrever.

Fique bem claro, em primeiro lugar, que o narrador não é uma instância pre-constituída, mas toma corpo no manuscrito e, idealmente, surge somente, como a Vênus emergindo das aguas bela e atraente, na entrega do manuscrito ao editor. A imagem usada pode incomodar mais de um manuscriptólogo, porque supōe uma evoluçāo em direçāo a um texto perfeito e compara o manuscrito ao embriāo. Ousaremos, no entanto, defender essa hipótese por enquanto, para matiza-la em seguida.

Voltemos a nossa atenção para o engendramento do múltiplo literário pelo um, em seu nível inconsciente. Detenhamo-nos primeiro sobre o fenômeno da rasura, fenômeno simples aparentemente e comum a todos os que escrevem, adquirindo entre os escritores, no entanto, uma importância enorme, na maioria dos casos.

O que incentiva o escritor a rasurar? Sob a injunçāo de quais forças, o scriptor reage? Ou melhor, o que se trama entre o escritor e essa terceira força que quebra a relação especular estabelecida entre o eu do escritor e a página

${ }^{4}$ Le désir du narrateur et l'apparition de Jean-Baptiste dans le manuscrit d'Hérodias. Littérature. Paris, Larousse, 1983. p. 112. 
branca? O escritor já desdobrado em scriptor e leitor ${ }^{5}$, imóvel no suspense da escritura por um tempo indefinido que pode cobrir um segundo ou dias, sai do mundo das significações cotidianas construído pelo homem, escapa ao mundo do sentido comum e, numa atitude passiva e feminina, escuta vozes e recebe informaçōes de um mundo que o ultrapassa, engloba o real lacaniano, seu passado pessoal e sua memoria e, neste momento, perde sua característica habitual, o esquecimento. O suspense da escritura, termo de Juranville ${ }^{6}$, confere-lhe poder sobre esse mundo, fascinante, numa primeira etapa, e do qual, em seguida, ele destaca objetos transformando-os em escritura.

Os antigos, bem menos narcisistas que os modernos, tinham divinizado tal mundo e o dividiram em nove, segundo as artes e as ciências concernidas: a Historia, a Comédia, a Tragédia, a Dança, a Elegia, a Poesia Lírica, a Astronomia e a Eloqüência. Poderíamos retomar essas divindades sem mais separálas segundo os gêneros, imaginando fazerem parte desse mundo extraordinário que toca o escritor de uma maneira bem particular.

A rasura adquire, assim, uma importância excepcional, porque constitui um dos momentos privilegiados do contato entre o escritor e esse mundo. Mundo vastíssimo, muito maior do que o texto publicado permite suspeitar, mas cuja vastidão o manuscrito deixa entrever. No entanto, são zonas desconhecidas que ultrapassam de longe o próprio manuscrito, os cadernos de anotaçōes ou a correspondência do escritor ${ }^{7}$.

Cefendemos aqui a existência de um elemento aglutinador, "o primeiro texto" 8 . Na sua vida de pulsões e de desejos, o escritor, para não dizer o artista em geral, particularmente sensível à tradição cultural e ao mundo em que vive, retém de forma singular informações e sensaçōes do passado e do presente. Os elementos detidos nesse filtro particular formam um entrelaçamento, um nó, que bloqueia, de certo modo, o desejo do artista e o incomoda. Desse bloqueio, nascem o primeiro texto e o autor. Não há, portanto, um primeiro texto escrito em alguma parte transmitido por uma musa a um escritor atento, mas há uma lenta aglutinação de elementos que, depois de um certo tempo, devem ser ditos e escritos. Como o neurótico angustiado por seu sintoma recorre ao psicanalis$\mathrm{ta}$, assim o escritor, querendo se livrar dessa placa retida, começa a escrever. Não há semelhança pela forma, nem pelo conteúdo entre esse primeiro texto e o texto publicado. Este não reproduz ipsis litteris o primeiro texto, nem as informações nele contidas. Diria que há uma relação sintomal entre os dois. Da mesma maneira que para dizer sua paixão à amada, ou eliminar seu sintoma, o amante, ou o analisando, precisa de tempo e de linguagem, assim o escritor necessita do tempo da escritura para se livrar desse bloqueio que o inquieta.

Esse primeiro texto tem a ver com a "cripta" de Nicolas Abraham e Marie Torok $^{9}$ e permite certamente a algumas dessas palavras fossilizadas presas ao inconsciente pessoal do escritor de reviver pela escritura.

"Primeiro texto", porque ele dará sua origem ao conto, ao romance ou à poesia, uma origem mítica, ou melhor, lógica, que distinguirá um conto do ou-

5 GRÉSILLON, A. e LEBRAVE, J. Langage. Paris, Larousse, 1983. p. 9.

${ }^{6}$ Lacan et la philosophie. Paris, PUF, 1964. p. 377-78.

7 Divergimos aqui da tese de Almuth Grésillon, que analisou a rasura como censura e lugar da falha em "Les silences du manuscrit". Edição crítica e crítica genética. São Paulo, FFLCH/USP, 1989.

8 WILlemarT, P. Conceitos de manuscritologia. Folha de S. Paulo, 5, fev. 1988. Folhetim, p. B3.

${ }^{9}$ Le verbier de Thomme au loup. Paris, Flammarion, 1976. 
tro, Herodias, de Saint-Julien, por exemplo. O primeiro texto incitará o escritor a consultar não somente a Btblia ou La légende dorée, de Voragine, mas a tomar tal nota de preferencia a tal outra, ou de iniciar uma viagem determinada em lugar de ficar no seu gabinete. Mesmo se o escritor acredita dirigir seu trabalho, sua escolha $\epsilon$ guiada tanto pelo seu ser empírico quanto por esse primeiro texto. Quando o escritor, sob a influência de tal nó ou tensão do primeiro texto, escolhe Félicité, Saint-Julien ou João Baptista, uma transferência se opera e precipita uma série de informaçōes, de sensaçōes, de dados que se ordenam aos poucos no manuscrito.

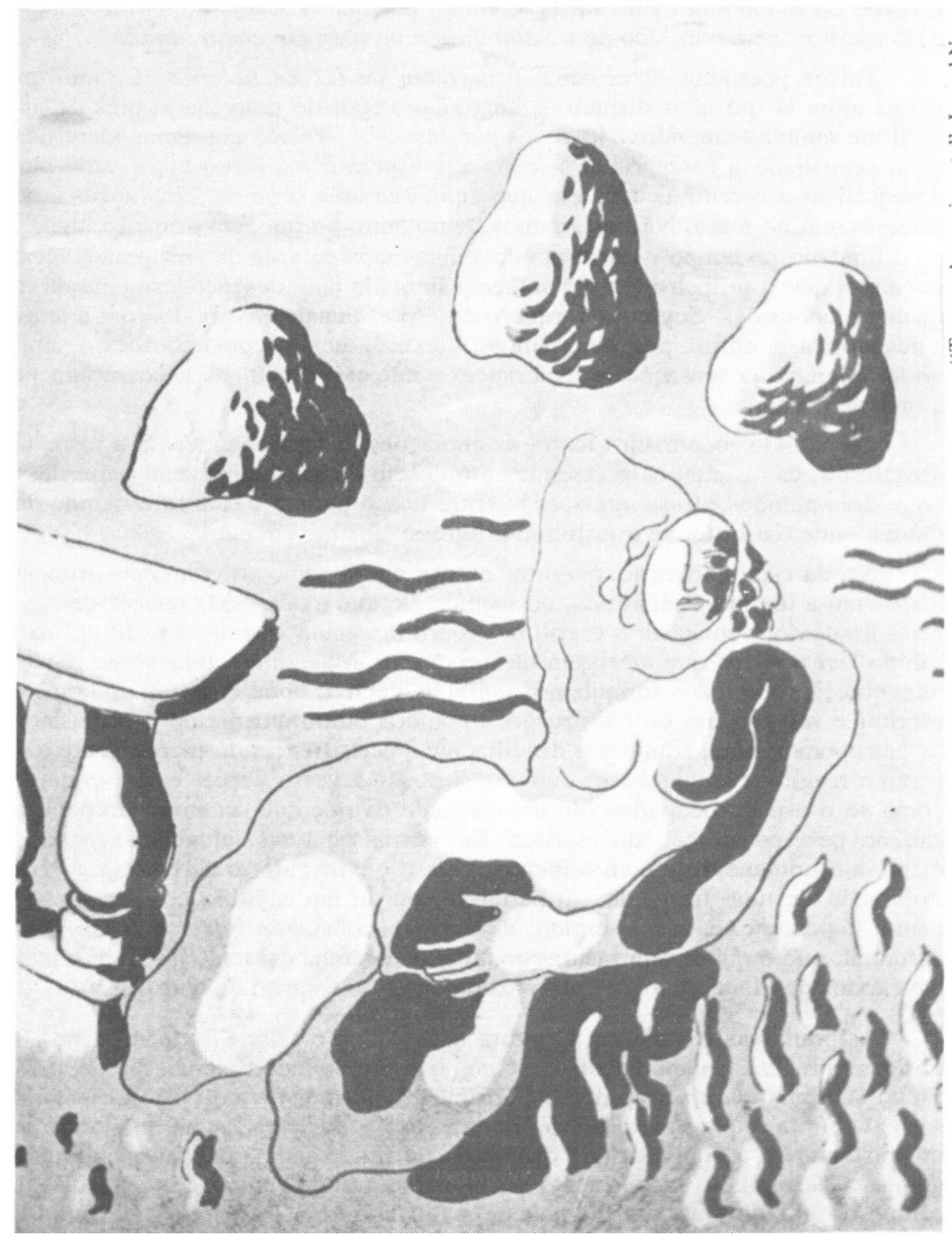

No II Congresso sobre o manuscrito, em setembro de 1988, uma escritora francesa, Paule Constant, nos deu seu testemunho a esse respeito. Em um de seus livros, descreve o inferno verde da bananeira sem nunca ter feito uma pesquisa apurada como Zola fazia; no entanto, falando um dia com o proprietário de um bananal, percebeu que seu mundo ficcional correspondia ao da realidade. O que tinha acontecido? Ela se lembrou então de que conheceu este mundo to- 
talmente esquecido e recalcado quando criança, esse mesmo mundo que tinha ressurgido pela escritura. O nó angustiante, origem do livro, esse primeiro texto, se formou muito cedo, e, porque reprimido, só podia emergir através de um processo analítico ou pela escritura ${ }^{10}$.

Lembremo-nos ainda do herói de Proust recordando-se de sua avó em Balbec. Torna-se de novo o neto de outrora, traz à memória uma série de acontecimentos e de sensaçōes que o fazem chorar. Transferência, lembrança, momento provocado ou acaso dos encontros forçarão a escolha do conto da mesma maneira que a segunda estada em Balbec nos dará algumas páginas a mais de La Recherche. Entendemos, então, por que o desejo do narrador não é o do escritor, nem o mesmo para Saint-Julien ou para Un coeur simple.

Talvez possamos dizer como o narrador de La Recherche: "Le moi que j'étais alors et qui afait disparu si longtemps, était de nouveau si près de moi qu'il me semblait entendre encore les paroles..."11. Talvez possamos identificar o eu proustiano a esse primeiro texto que espera o momento apropriado para desencadear a escritura, uma vez que congrega uma série de lembranças a desembocarem no texto. Não o faríamos, entretanto, porque, em primeiro lugar, o eu é limitado no tempo e corresponde a uma etapa da vida de uma personagem, enquanto que o primeiro texto $e$ somente limitado pelo desencadeamento da tomada de anotaçōes. Segundo porque o eu $\epsilon$ por demais envolvido com a teoria psicanalítica e, enfim, porque a palavra "texte", tecido, como Barthes o sublinhou, alinhava já sensações e lembranças e não está vinculada necessariamente a uma personagem.

Resumindo: o primeiro texto, as anotações, a correspondência a respeito, a escritura, as rasuras, os acréscimos e o desejo do narrador fazem parte desse entre-dois-mundos, dessa intersecção entre nosso mundo e este fora-mundo das musas, onde o escritor se transforma progressivamente em autor.

Aceita esta teorização, perguntamo-nos agora como articular este primeiro texto com a teoria psicanalítica, ou melhor, de que modo essas relaçōes entre o primeiro texto, anotações e escritura decorrem de um impensado, de um nãosabido (un non-su) que emergem de um desejo. Mas, antes, temos que rebater uma objeção que todos formulamos implicitamente e opõe o desejo do homemescritor e seu espírito de construção. Imbuídos culturalmente de positivismo e de antropomorfismo, admitimos dificilmente a coexistência do inconsciente e da razão e reagimos muitas vezes como se a razão devesse vencer o inconsciente, como se o espaço ocupado pelo inconsciente tivesse que ser invadido pela razão ou pela construção do escritor. Em outras palavras, identificamos facilmente a espontaneidade com o inconsciente e o corrigido, o acréscimo, a reestruturação de uma frase, de um parágrafo ou de um capítulo como a razão e com a lógica, etc. e, nesse sentido, deveríamos considerar o Henry Brulard, de Stendhal, que $\epsilon$ quase sem rasuras como o testemunha evidente do inconsciente e os textos de Flaubert como exemplos patentes do espírito de construção.

As premissas freudianas, a leitura lacaniana e o estudo do manuscrito nos obrigam a recusar a espontaneidade como o signo do inconsciente. Desde 1920, Freud sublinha que toda atividade humana, e não somente a do inconsciente, se sustenta em um fantasma, projeção de um desejo. Jacques Lacan, por outro lado, restaurando a equivocidade originária da linguagem - não há metalinguagem - e, definindo o inconsciente como o conjunto do campo, das pulsões e do campo do grande Outro (a linguagem, a Lei, o corpo, os terceiros, a tradição, etc.) subentende a relação imediata entre a escritura, o estilo e o inconsciente e a relação mediata entre tradição, cultura, arte e inconsciente (mediata porque passa pelo sujeito do inconsciente).

Rasurar não é, portanto, recalcar o inconsciente, mas, pelo contrário, deixá-lo desabrochar.

10 Ediçâo crítica... op. cit.

11 PROUST. La recherche... op. cit., v. II, p. 757. 
Rasurar não $\epsilon$, portanto, recalcar o inconsciente, mas, pelo contrário, deixá-lo desabrochar. "A letra escrita no papel, pelo fato de tentar (inconscientemente) re-produzir a ruptura que $\epsilon$ a inscrição inconsciente, realiza de fato um apagamento, uma sutura do corte", relata Leclaire ${ }^{\mathrm{I} 2}$. O vai-e-vem da abertura e do fechamento propulsiona a escritura. Primeira redação ou texto, a dimensão inconsciente está presente. $O$ gênio do artista tem esta vantagem de arremessar neste jogo de vai-e-vem muito mais do que a maioria dos homens e de captar pelas musas tanto a tradição que o sustenta quanto as tendências ou os desejos de seu povo e de sua cultura. No final do manuscrito, o escritor repetirá provavelmente a frase de Freud, característica do inconsciente: "eu nunca tinha pensado nisso".

Perguntamos se podemos, sem incoerência, batizar de inconsciente esse não-sabido (le non-su) que aparece no manuscrito e, muitas vezes, desaparece do texto editado. Tocamos aqui em um ponto nevrálgico. Fm artigo excelente sobre a teoria lacaniana, Jean Petitot ${ }^{13}$ conclui que Lacan produziu a equivocidade geral da ontologia. Levando essa equivocidade em conta, podemos talvez propor uma outra noção de inconsciente que decorre, no entanto, do inconsciente lacaniano.

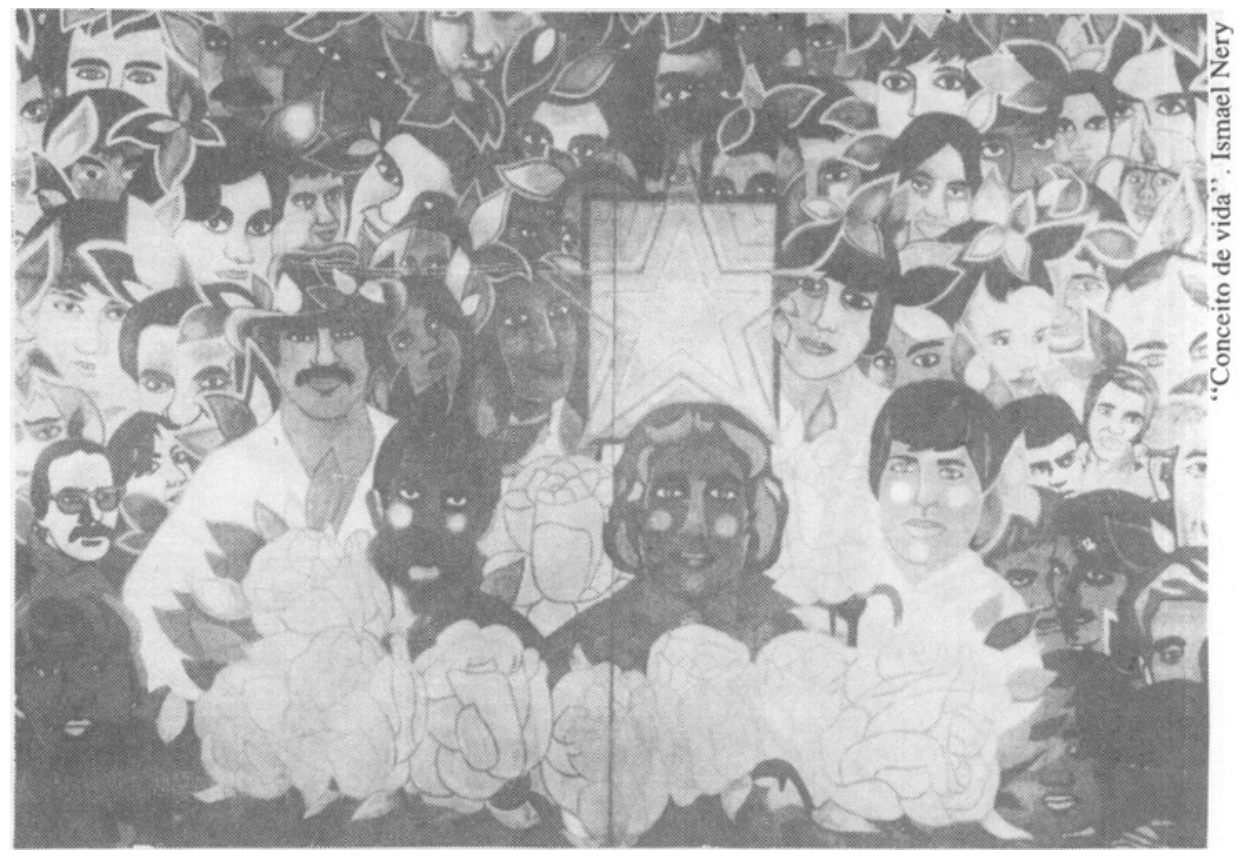

Freud, centrado sobre o Édipo, não pôde senão admirar a produção artística e confessar, como fazia no final do Leonardo que "o dom artístico e a capacidade de trabalho sendo vinculados à sublimação, a essência da função artística fica para nós psicanaliticamente inacessível"14. Por outro lado, sabemos que Freud não trabalhou muito o conceito de sublimação definido por ele em 1932, como uma espécie de modificação de alvo e de mudança de objeto, o qual entra em consideração nossa avaliação social. Podemos dizer que Lacan, tão inserido na sua cultura e seduzido pelos artistas quanto Freud, foi mais lon-

12 La stratégie du langage. Littérature et Psychanalyse. Littérature. Paris, Larousse, 1971. p. 32 .

13 "E(n)trave". Analytica 10. Ornicar. Paris, Ed. Le champ freudien, suplemento n 14 junho de 1978. p. 31.

14 Un souvenir d’ enfance de Leonard de Vinci. Paris, Gallimard, 1977. p. 149-150. 
ge na compreensão do ato da criação. No capítulo XI do Le Séminaire sobre o olhar, ele afirma, em resumo:

O artista (trata-se do pintor) cria:

19) para responder a um desejo suscitado por uma sociedade, uma instituição, um marchand, uma mulher, todos sequiosos de porem seu olho voraz sobre um quadro para acalmá-lo e tranquiiliza-lo. Nesse sentido, o inconsciente é o discurso do grande Outro.

29) teleguiado pelo desejo ao grande Outro. Lacan lembra o filme em câmera lenta que mostra Matisse pintando: "No ritmo onde chova do pincel do pintor esses pequenos toques que formarão o milagre do quadro, não se trata de escolha, mas de algo de diferente"15.

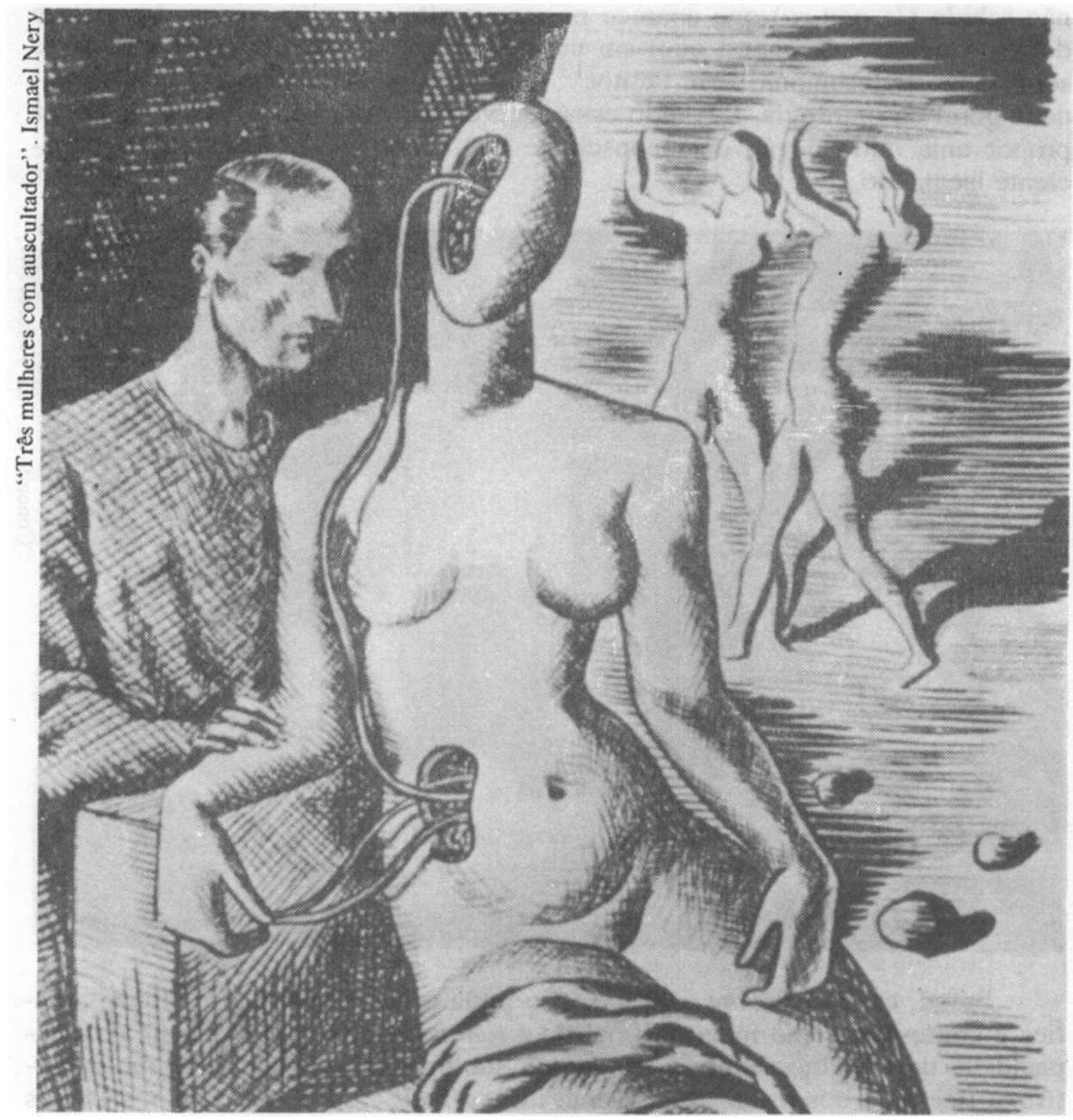

Entre o desejo do grande Outro e o desejo ao grande Outro, surge a obra, efeito da sublimação onde "a coletividade encontra o campo do descanso pelo qual ela pode de uma certa maneira se iludir sobre Das Ding e colonizar este campo com suas formaçōes imaginárias"16.

15 Le séminaire. Livre XI. Paris, Seuil, 1973. p. 103.

16 Id., Le séminaire. Livre VII. Paris, Seuil, 1978. p. 118. Das Ding, a Coisa, é o objeto fundamental do desejo, o grande Outro inicial ocupado normalmente pela mãe. Simbolizando o gozo absoluto, a Coisa suscita o desejo do homem e a impossibilidade de sua satisfaçāo. 
Se Lacan deu um salto imenso em relação a Freud, resguardando a criação artística das pulsôes para situá-la no campo do grande Outro, ele não diz nada, segundo o que sabemos, do que se passava entre o desejo do grande Outro e o desejo ao grande Outro, espaço atualmente objeto de estudos recentes, o manuscrito, onde funciona o que definimos como "inconsciente genético".

Ilustraremos este inconsciente por alguns fatos destacados do manuscrito de Hérodias que, curiosamente, não aparecem mais no texto editado, mas ajudam o leitor atento a compreender melhor o conto. São eles: a pluralidade religiosa do tetrarca e sua hesitação entre as crenças árabes, judias ou romanas; a indiferenciação das personagens Antipas e Hérodias visível nos lapsos de escritura; as relações amorosas de caráter divino entre Iaokanann e Antipas; a genealogia nova traçada entre Josue, Amos, Iaokanann e Antipas; o anagrama quase perfeito entre o sacerdote de Jeroboam II, Amasias, que expulsou Amos e o primeiro nome do carrasco samaritano que matará Iaokanann, Amasai; a denegação da angústia em Antipas, apesar dos perigos iminentes; a condensação Amos-Josué; a posição arreligiosa do narrador quando retoma a profecia de Ezequiel; o saber decorrente da fascinação do escritor pela Bíblia e pelo Etude critique sur la Bible, de Nicolas Michel, etc. 17

Tais fatos dispersos no manuscrito do primeiro capítulo de Hérodias não são certamente os únicos que decorrem do inconsciente genético, mas nenhum deles tem a ver com os outros dois contos de Flaubert escritos na mesma época. Fazem parte de um não-sabido (un non-su) para o leitor, mas não de um impensado para o narrador que os conhece, os condensa e os elimina. São eles parecidos com os elementos latentes do sonho, não-sabidos do sonhador, mas pensados pelo agenciamento onírico? Eles estão ativos, desencadeiam o sonho narrado e, aqui, o texto publicado. O manuscrito se torna assim o similar do sonho em estado latente, salvo que ele $\epsilon$ diretamente acessível e suscetível de interpretação para um bom crítico.

O impensado existe, no entanto, para o escritor e seu narrador, e se confunde com o primeiro texto que colocamos no nível das sensaçóes ou do afeto e ao redor do qual nasce esse novo saber que aparece no manuscrito. Sublinhamos "ao redor de" ou "na beira de", onde reencontramos a descrição lacaniana do inconsciente, a falha que suscita, conduz e leva o barco, mas não aparece nos rascunhos.

Se quisermos uma referência mais clara a respeito desse impensado, podemos citar o excelente livro, em sete volumes, intitulado: Des mots à la pensée. Essai de grammaire de la langue française, onde o filologo Jacques Damourette e seu sobrinho psiquiatra e psicanalista, Edouard Pichon, tentam discernir os mecanismos e as idéias da língua francesa que constituem o impensado da língua. Lacan, que os apreciava, fazia alusão a essa obra e até se inspirou dela para alguns de seus conceitos. Nós falamos sem o saber, isto $\epsilon$, sem conhecer esse impensado que modela inconscientemente nossa fala.

Devemos, entretanto, distinguir esse impensado social do impensado do primeiro texto, singular e não mais comum a todos, decorrente também de um afeto, mas que ficará desconhecido a maior parte do tempo. Paradoxalmente, os dois impensados se aliam na sua dimensão social. O primeiro pela língua, como o demonstram suficientemente Damourette e Pichon e o segundo pelo viés do leitor ou do público receptor. O prazer da leitura não é somente devido a uma cultura reencontrada como o definia Barthes, mas tambem a uma comunidade de desejos e de afetos entre o autor e seu leitor. Esbarramos de novo com o gênio do escritor que, com as antenas atentas, ultrapassa os horizontes do homem comum, se abre ao além e ao aquém e pode reunir seus contemporâneos e, muitas vezes, as gerações futuras em um conjunto de aspirações que atravessam

17 WILLEMART, P. Contribution de la théorie de l'inconscient à la critique génétique. $O$ manuscrito moderno e as edições. São Paulo, FFLCH/USP, 1986. p. 303. 
os homens, mas que ele verbalizará, como os gramáticos fazem com a língua. Seria difamar Flaubert, Balzac, Stendhal ou Proust se os comparássemos a gramaticos encarregados de dizer como e por que seus contemporâneos falam, pensam e imaginam no presente e no futuro, estando a diferença no fato de que o gramático constata fatos, enquanto o escritor, além de constatar, anuncia e denuncia? Retomando a comparação, podemos dizer que o impensado, sublinhado por Damourette e Pichon, se associa ao passado do inconsciente freudiano, ao passo que o anunciado pelos escritores se aproxima do imprevisto lacaniano, dado fundamental de sua concepção do inconsciente.

Desse impensado ou desse primeiro texto, surge o desejo do narrador, desejo específico a cada conto, canal natural do desejo do escritor. Desejo do escritor, primeiro texto, desejo do narrador. Chegamos assim ao un, ao que, aparentemente, é comum aos três contos, o escritor Flaubert, seu desejo, sua neurose, seu sujeito do inconsciente.

- O desejo do escritor, bloqueado por esse impensado do primeiro texto, suscita a pulsão de escrever atraída pelo desejo ao grande Outro. Entre este desejo do grande Outro e este desejo ao grande Outro, o escritor se debate, escreve, rasura e está obrigado a modificar sua relação com o inconsciente. O escritor também muda. O de Saint-Julien não é mais exatamente o de Un coeur simple ou de Hérodias. Não porque ele faz ressurgir elementos recalcados como reza a teoria freudiana, mas porque, pela escritura, ele faz significar elementos que, antes, não tinham a menor importância, ou ainda, porque ele inclui, no mundo, elementos até então ignorados ${ }^{18}$. E, evidentemente, não são somente seus leitores que se aproveitam disso, mas ele próprio, como primeiro leitor. Portanto, há sublimação, gozo e modificação.

Quais são essas coisas que, subitamente, significam ou que emergem do real no manuscrito em nível do sujeito do inconsciente de Flaubert? Pergunta vã, pois só ele poderia responder. Mas, não $€$ totalmente sem razão que Sartre, apesar das restriçōes de Jean Bruneau, viu relaçōes entre o parricídio de Julien no conto; Gustave, o escritor, e seu pai, Achille-Cléphas, ou, também, que Flaubert confunde as personagens Hérodias e Antipas no manuscrito, e assim por diante. Mas insistimos, tudo isto não é senão uma série de extrapolaçōes que, na ausência do escritor, se tornam elucubraçōes.

Para concluir, podemos, em primeiro lugar, retomar a corrente não-linear, mas complexa que sai do desejo do escritor. Bloqueado por um primeiro texto, conjunto de impressóes, de sensaçōes e de chamadas do grande Outro, o desejo da partida à pulsāo de escrever. Comprimido entre o convite ao grande Outro os terceiros que o solicitam nos silêncios e nas rasuras - e sua neurose, o escritor, às vezes scriptor, às vezes leitor, se torna autor e vê emergir um texto novo, original e significante, que trabalha sua relaçăo com $o$ inconsciente $e$ com o dos seus leitores.

Em segundo lugar, qualificamos de inconsciente genético o conjunto das novidades que surgem no espaço do manuscrito e que năo decorrem necessariamente do inconsciente ou da relação do escritor com o grande Outro, mas do autor com esse grande Outro. Especificamente sensivel aos chamados da tradição, do momento ou do futuro, o escritor capta dados, revaloriza coisas esquecidas ou inclui elementos renegados até entāo.

Em terceiro lugar, considerando as forças que agem no manuscrito, forças originais para cada texto, considerando a sublimação que sofre o escritor por sua passagem à instância de autor em cada um de seus textos, só podemos concluir que, psicanaliticamente falando, os Três contos constituem três textos diferentes, apesar da mesma assinatura que os une.

18 JURANVILLE, Lacan et la... op. cit., p. 244.

Philuppe Willemart é professor-titular de Literatura Francesa no Departamento de Letras Modernas da FFLCH/USP. 